\title{
The Wealth Tax of 1942 and the Disappearance of Non-Muslim Enterprises in Turkey - ERRATUM
}

\author{
Seven AĞir and Cihan ArtunÇ
}

doi: 10.1017/S0022050718000724, Published 14 March 2019 for The Economic History Association by Cambridge University Press.

In the online posting of this article (Ağır, S., \& Artunç, C. (2019). The Wealth Tax of 1942 and the Disappearance of Non-Muslim Enterprises in Turkey. The Journal of Economic History 79(1), 201-243. doi:10.1017/ S0022050718000724), the name of author Cihan Artunç was misspelled on the online Contents page. The online Contents page has since been corrected.

The publisher apologizes for this error.

\section{REFERENCE}

Ağır, S., \& Artunç, C. “The Wealth Tax of 1942 and the Disappearance of Non-Muslim Enterprises in Turkey." Journal of Economic History 79, no. 1 (2019): 201-243. doi:10.1017/S0022050718000724 